\title{
PENGARUH VARIASI JARAK SENGKANG KOLOM UNTUK RUMAH SEDERHANA TERHADAP BEBAN GEMPA DI PADANG
}

\author{
Febrin Anas Ismail ${ }^{1}$
}

\begin{abstract}
ABSTRAK
Gempa yang terjadi di Sumatera Barat merusak banyak bangunan terutama untuk rumah sederhana (non-engineered house). Kerusakan ini sebagian disebabkan oleh kegagalan struktur pada kolom, yang diakibatkan oleh jarak sengkang yang tidak mengkuti peraturan yang ada. Minimnya pengetahuan masyarakat tentang fungsi sengkang yang ada di kolom juga menimbulkan korban jiwa yang cukup besar.

Penelitian ini bertujuan untuk mengetahui pengaruh variasi jarak sengkang kolom untuk rumah sederhana terhadap beban gempa. Pemodelan struktur kolom dibuat dengan menggunakan dua buah portal dengan variasi jarak sengkang $20 \mathrm{~cm}$ dan $30 \mathrm{~cm}$, portal akan diuji dengan metoda pushover. Pembacaan beban dilakukan tiap $2 \mathrm{~mm}$ dan dilihat perilaku kedua portal yang diuji secara perlahan-lahan dengan actuator. Hasil yang didapat adalah keruntuhan yang terjadi adalah akibat lentur, bukan terhadap geser. Semakin rapat jarak sengkang, semakin tinggi kekakuannya, karena beton disekitarnya ter-confined dengan baik.
\end{abstract}

Kata Kunci : Gempa bumi, variasi jarak sengkang, gaya geser.

\section{PENDAHULUAN}

Gempa bumi adalah getaran yang terjadi permukaan bumi yang biasa disebabkan oleh pergerakan kerak bumi (lempeng bumi). Kebanyakan gempa bumi disebabkan dari pelepasan energi yang dihasilkan oleh tekanan yang dilakukan oleh lempengan yang bergerak satu sama lain. Semakin lama gerakan tersebut menghasilkan suatu energi yang kian membesar dan akhirnya mencapai pada keadaan dimana tekanan tersebut tidak dapat ditahan lagi oleh pinggiran lempengan. Pada saat itulah gempa bumi akan terjadi dan gempa bumi terjadi apabila tekanan yang terjadi karena pergerakan itu sudah terlalu besar untuk dapat ditahan.

Gempa di daerah Tanah Datar (Sumatera Barat) merusak banyak bangunan terutama untuk rumah sederhana (non-engineered house). Untuk rumah rusak berat sebanyak 3.110 buah, rusak sedang 3.437 buah dan rusak ringan 3.551 buah. Untuk Sekolah rusak berat 68 buah, rusak sedang 30 dan rusak ringan 40. Untuk kantor rusak berat 18 buah, rusak sedang 9 buah dan rusak ringan 10 buah. Untuk mesjid/ mushalla rusak berat 74 buah, rusak sedang 28 buah dan rusak ringan 48 buah.

Selain kerusakan materil, gempa bumi juga menyebabkan timbulnya korban jiwa akibat keruntuhan bangunan, yang diakibatkan oleh kegagalan struktur terutama pada kolom. Jumlah korban tewas dalam bencana ini pada tanggal 6 Maret dilaporkan mencapai 79 orang, sedangkan pada tanggal 12-13 September 2007 dilaporkan tidak ada korban jiwa.

Oleh karena itu dirasa perlu suatu kajian khusus mengenai bagaimana konstruksi bangunan yang baik, khususnya dalam perencanaan jarak efektif sengkang kolom pada rumah non-engineered yang berada di daerah rawan gempa. Kajian ini dapat berupa suatu perilaku atau kesimpulan

\footnotetext{
${ }^{1}$ Staf Pengajar Jurusan Teknik Sipil Fakultas Teknik Universitas Andalas, e-mail: febrin@ft.unand.ac.id
} 
terhadap kemampuan pengaruh jarak sengkang suatu kolom dalam menerima beban gempa, baik gempa kecil, sedang, maupun gempa besar.

Penelitian ini bertujuan untuk melihat perilaku kolom berupa pola retak pada kolom dan perpindahan yang terjadi akibat beban gempa statis dengan metoda pushover. Manfaat dari penelitian sebagai pertimbangan dan acuan dalam perencanaan struktur bangunan, khususnya dalam mendesain jarak efektif sengkang kolom yang dalam perencaanaan rumah sederhana (nonengineered) di Padang.

\section{PELAKSANAAN PENGUJIAN}

\subsection{Perencanaan Benda Uji}

Benda uji yang akan diteliti adalah model skala penuh (full scale model) variasi jarak sengkang kolom dalam perencaanaan rumah sederhana. Pemilihan variasi jarak sengkang kolom ini bertujuan untuk menentukan jarak efektif sengkang yang baik untuk digunakan.

Pada eksperimen ini dibuat dua buah portal, dengan data-data sebagai berikut :

$\begin{array}{ll}\text { - Ukuran kolom } & : 13 \mathrm{~cm} \times 13 \mathrm{~cm} \\ \text { - Ukuran balok } & : 11 \mathrm{~cm} \times 13 \mathrm{~cm} \\ \text { - Mutu beton } & : f_{c}^{\prime}=17,5 \mathrm{MPa} \\ \text { - Mutu tulangan lentur } & : f_{y}=240 \mathrm{MPa} \\ \text { - Mutu tulangan geser } & : f_{y}=240 \mathrm{MPa} \\ \text { - Diameter tulangan utama } & : \varnothing 10 \mathrm{~mm} \\ \text { - Diameter tulangan sengkang } & : \varnothing 6 \mathrm{~mm} \\ \text { - Variasi jarak sengkang } & : \varnothing 6-20 \mathrm{~cm} \text { dan } \varnothing 6-30 \mathrm{~cm}\end{array}$

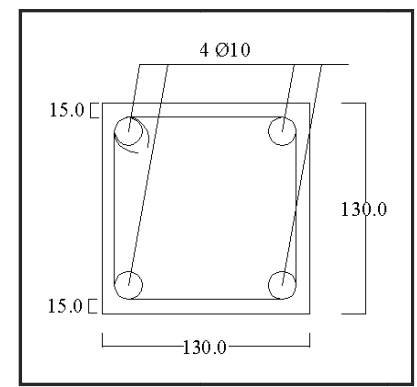

Gambar 1. Penulangan Kolom

\subsection{Material Beton dan Baja}

Campuran beton menggunakan semen normal (semen tipe 1), yaitu semen yang dapat digunakan secara umum tanpa persyaratan tertentu. Beton yang digunakan untuk benda uji direncanakan dengan mutu $175 \mathrm{~kg} / \mathrm{cm}^{2}$ dengan perbandingan campuran 1 semen : 2 pasir : 3 kerikil. Baja tulangan yang digunakan terdiri dari tulangan ulir dan tulangan polos dengan tegangan leleh aktual $240 \mathrm{MPa}$.

\subsection{Instrumentasi dan Setup Pengujian}

Alat ukur yang digunakan pada penelitian ini adalah dial perpindahan. Sedangkan alat uji pembebanan yang digunakan dalam penelitian adalah actuator dengan kapasitas 5 ton, digunakan untuk memberikan beban horizontal pada benda uji. Setup pengujian dan sistem pembebanan pengujian dapat dilihat pada Gambar 2. 


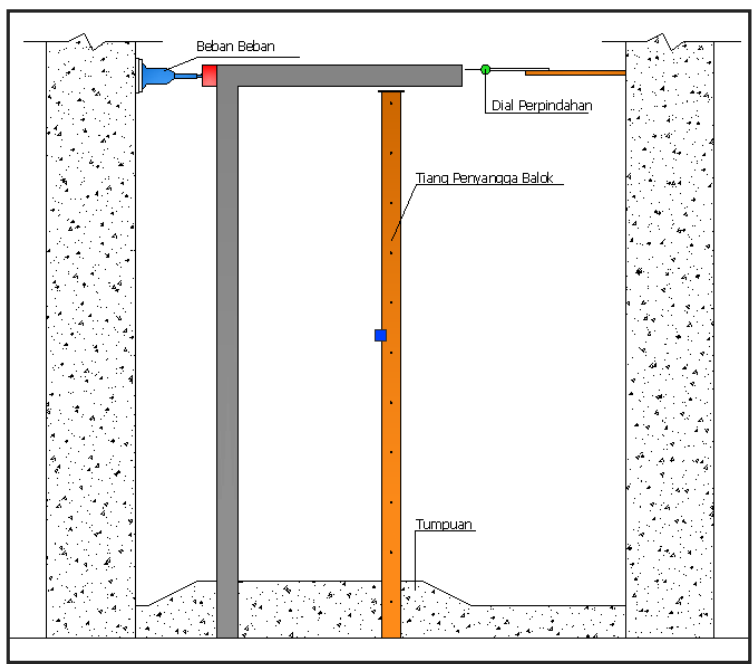

Gambar 2. Setup Pengujian Benda Uji

Pengujian dilakukan dengan langkah-langkah sebagai berikut:

a. Memakukan papan pada bidang masif sebagai peredam dan beban dari actuator tidak langsung bersentuhan dengan bidan masif.

b. Beban pushover (actuator) yang telah dipersiapkan, diposisikan pada bidang masif dalam arah horizontal dititik benda uji yang akan diberikan dorongan, seperti terlihat pada Gambar 3.

Gambar 3. Actuator

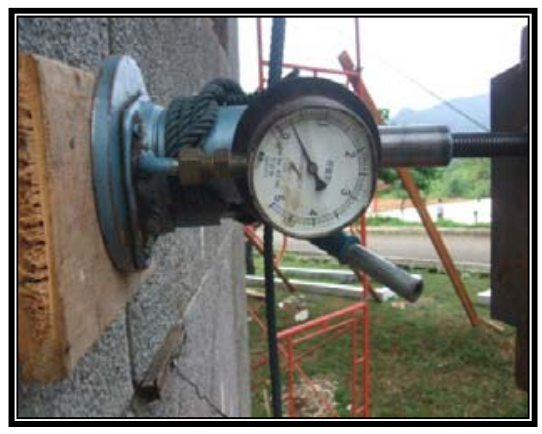

c. Setelah posisi beban tepat, maka kemudian dipasang dial untuk membaca besar perpindahan $(\delta)$ yang terjadi pada ujung balok, seperti pada Gambar 4.

\section{Gambar 4. Dial Perpindahan}

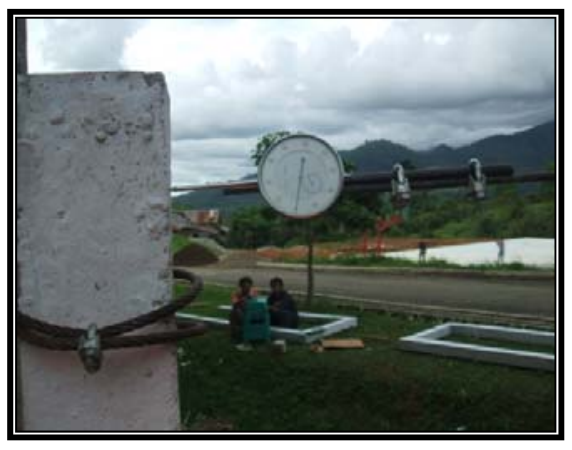

d. Dengan memberikan beban pushover, benda uji didorong sebesar $P$ secara bertahap sampai benda uji mengalami perubahan (keruntuhan).

e. Setelah itu diamati dan dicatat perubahan yang terjadi baik itu pada kolom dan balok dengan mencatat besar deformasi yang terjadi atau pola retak yang ditimbulkan pada benda uji. 
f. Prosedur di atas dilakukan kepada kedua benda uji. Dokumentasikan perubahan yang terjadi pada setiap benda uji dan dilakukan analisa manakah yang lebih baik (jarak sengkang $20 \mathrm{~cm}$ atau $30 \mathrm{~cm}$ ).

\section{ANALISA DAN PEMBAHASAN HASIL PENGUJIAN}

\subsection{Pola Retak}

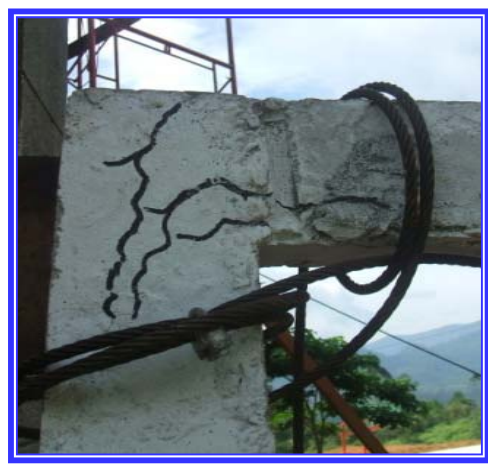

(a). Depan

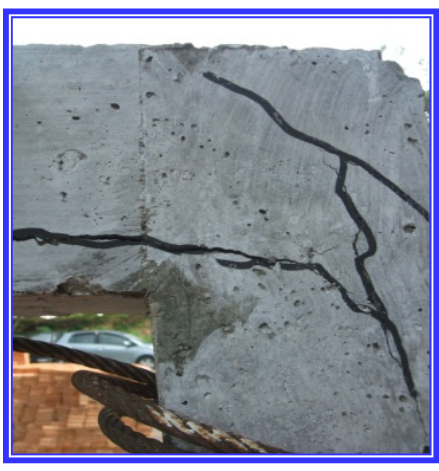

(b). Belakang

Gambar 5. Pola Retak Balok Bagian Kiri untuk Jarak Sengkang 30 cm

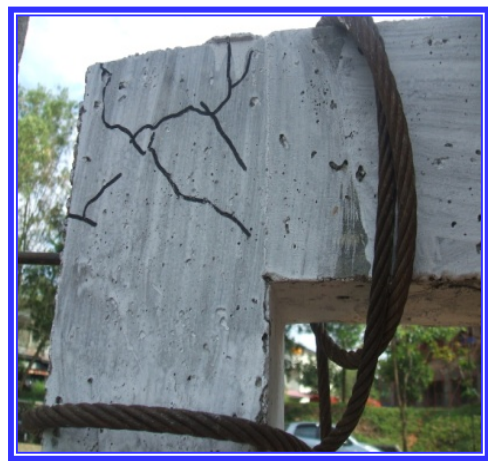

(a). Depan

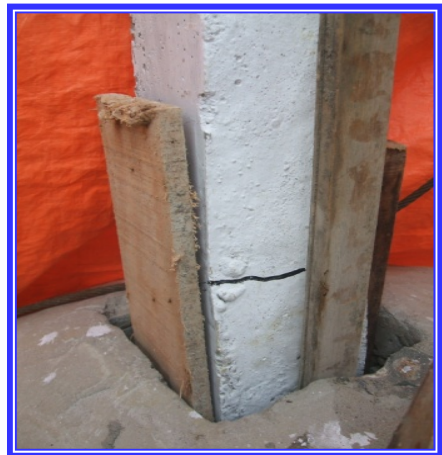

(b). Belakang

Gambar 6. Pola Retak Balok Bagian Kanan untuk Jarak Sengkang 30 cm

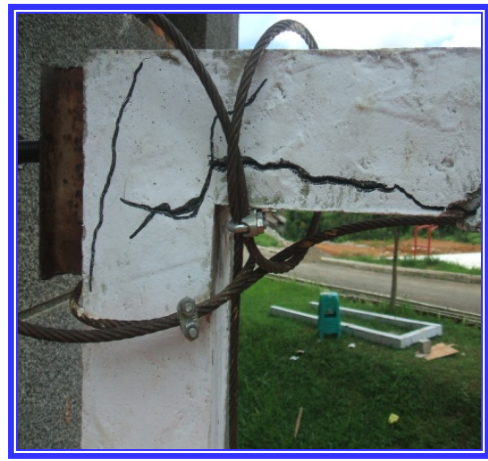

(a). Depan

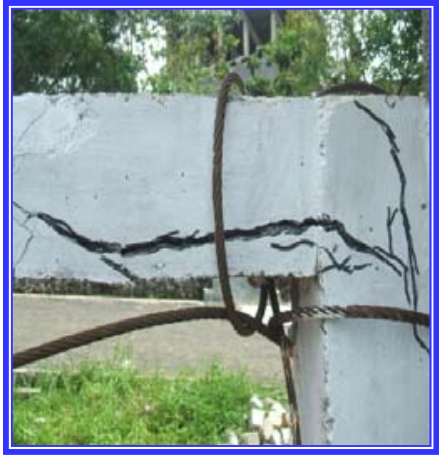

(b). Belakang

Gambar 7. Pola Retak Balok Bagian Kiri Pada untuk Sengkang 20 cm 


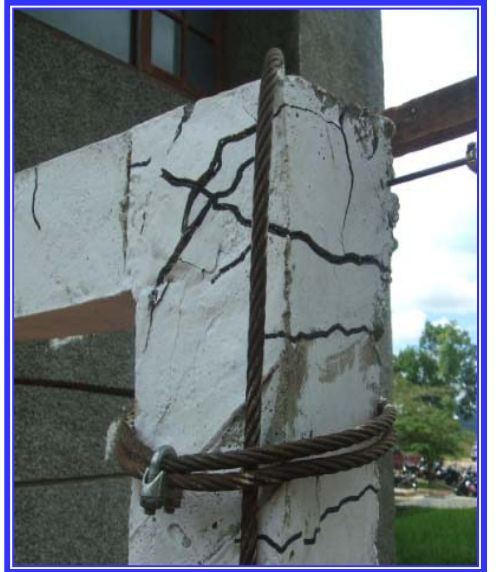

(a). Depan

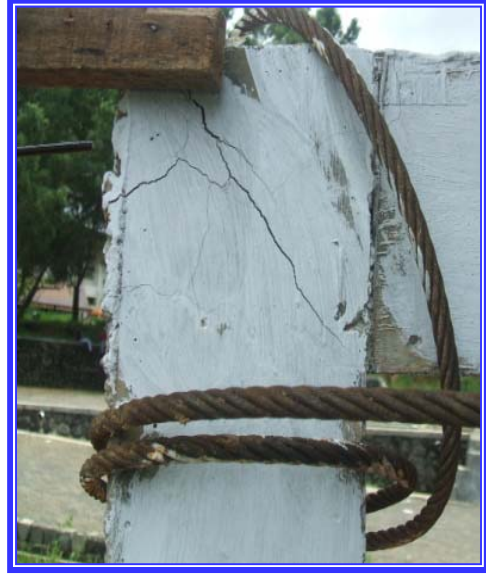

(b). Belakang

Gambar 8. Pola Retak Balok Bagian Kanan untuk Jarak Sengkang 20 cm

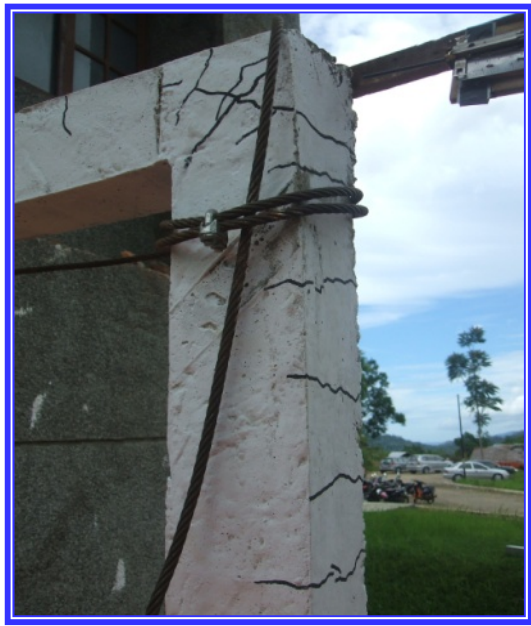

Gambar 9. Pola Retak pada Balok dan Kolom untuk Jarak Sengkang 20 cm

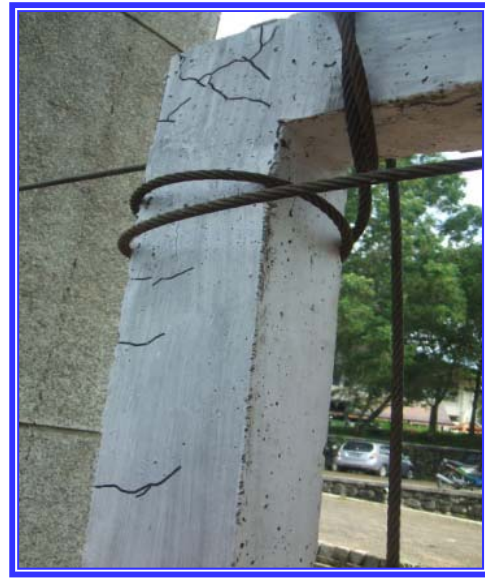

(a). Jarak Sengkang Kolom $30 \mathrm{~cm}$

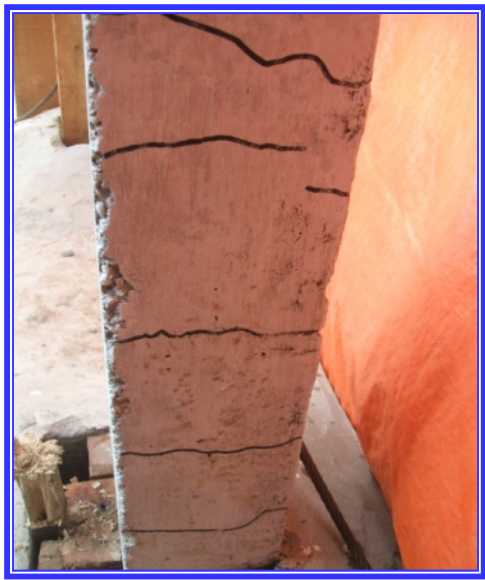

(b). Jarak Sengkang Kolom $20 \mathrm{~cm}$

Gambar 10. Pola Retak Minor Kolom untuk Jarak Sengkang (a).30 cm, (b). 20 cm 


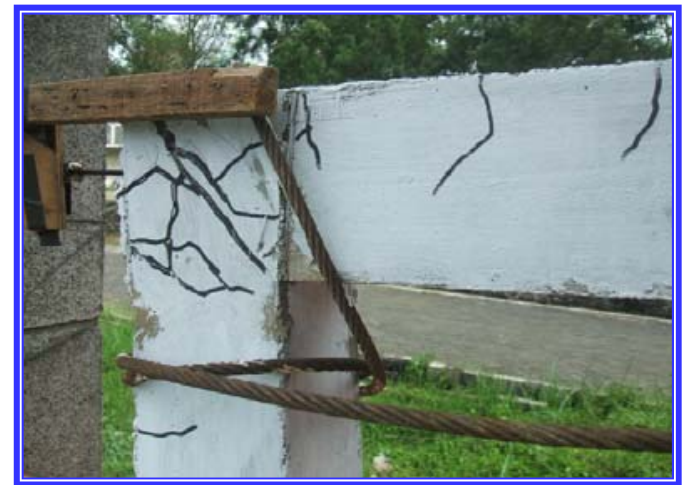

\section{Gambar 11. Beton Mulai Hancur untuk Jarak Sengkang 20 cm}

Dari pola retak di atas, dapat dianalisa bahwa balok terlebih dahulu hancur, karena secara langsung menahan beban yang diterima dari aktuator, kemudian disusul dengan retak yang terjadi pada kolom. Retak yang terjadi pada pengujian ini adalah retak lentur, hal ini terjadi karena gaya yang disebabkan oleh momen lebih dominan dibandingkan dengan gaya yang terjadi akibat geser. Gaya geser yang terjadi masih cukup kuat dipikul oleh penampang akibat gaya luar yang terjadi, pada jarak sengkang $30 \mathrm{~cm}$ maupun pada jarak sengkang $20 \mathrm{~cm}$.

Pola retak yang terjadi pada portal dengan jarak sengkang $20 \mathrm{~cm}$ dan $30 \mathrm{~cm}$ relatif sama. Pada benda uji dengan jarak sengkang $30 \mathrm{~cm}$, retak terjadi secara diagonal dan horizontal pada balok sejauh kurang lebih $10 \mathrm{~cm}$. Namum retak horizontal tidak sesuai dengan literatur-literatur yang ada, hal ini terjadi karena tulangan geser yang slip sehingga fungsi tulangan gsesr tidak berpengaruh pada kondisi ini. Sedangkan balok dengan jarak sengkang $20 \mathrm{~cm}$, retak terjadi sejauh kurang lebih $20 \mathrm{~cm}-25 \mathrm{~cm}$ dengan pola retak yang sama dengan benda uji dengan jarak sengkang $30 \mathrm{~cm}$.

Retak yang terjadi pada bagian kolom terletak pada bagian tarik, namun keretakan yang terjadi akibar geser sangatlah kecil (Gambar 9).

\subsection{Hubungan Beban - Perpindahan}

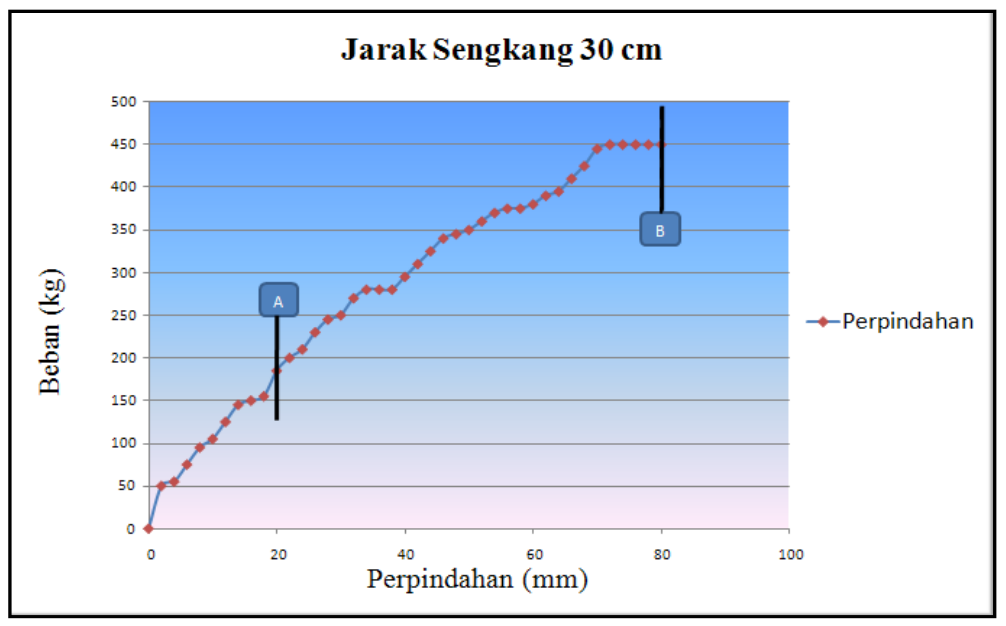

Gambar 12. Kurva Beban vs Perpindahan untuk Jarak Sengkang 30 cm

Kurva hubungan beban $(P)$ dan besarnya deformasi $(\delta)$ yang terjadi pada portal untuk jarak sengkang $30 \mathrm{~cm}$ ditunjukkan pada Gambar 12. Pada Gambar 12 dapat disimpulkan bahwa, pada jarak sengkang $30 \mathrm{~cm}$, beban maksimum yang dapat diterima portal adalah $450 \mathrm{~kg}$ dan besar 
perpindahan maksimum yang dapat diterima adalah $80 \mathrm{~mm}$. Pada jarak sengkang $20 \mathrm{~cm}$, beban maksimum yang dapat diterima portal adalah $450 \mathrm{~kg}$ dan besar perpindahan maksimum yang dapat diterima adalah $114 \mathrm{~mm}$. Kondisi tersebut dapat dilihat pada Gambar 13.

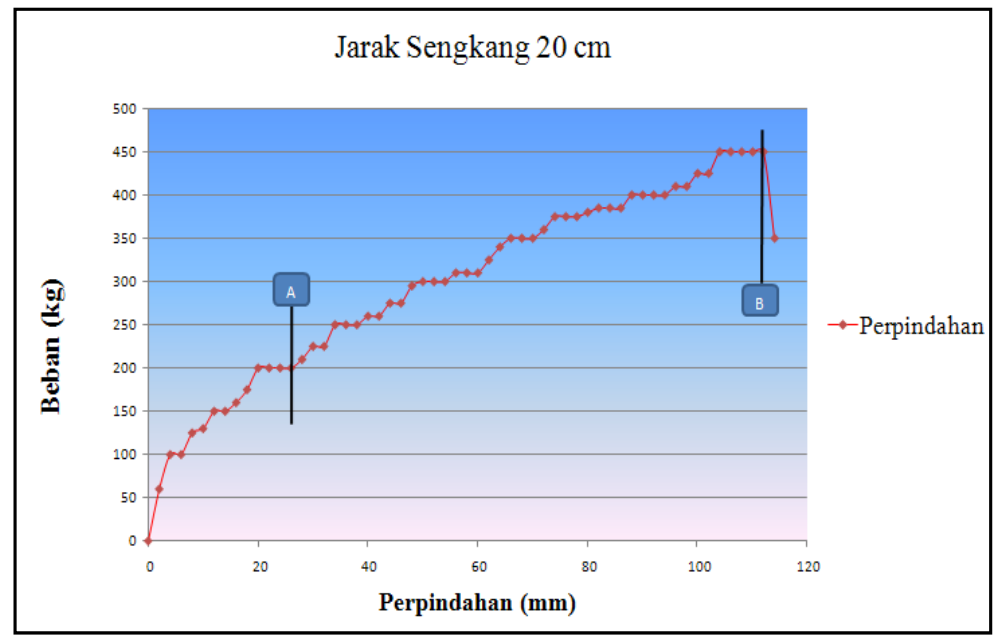

Gambar 13. Kurva Beban vs Perpindahan untuk Jarak Sengkang 20 cm

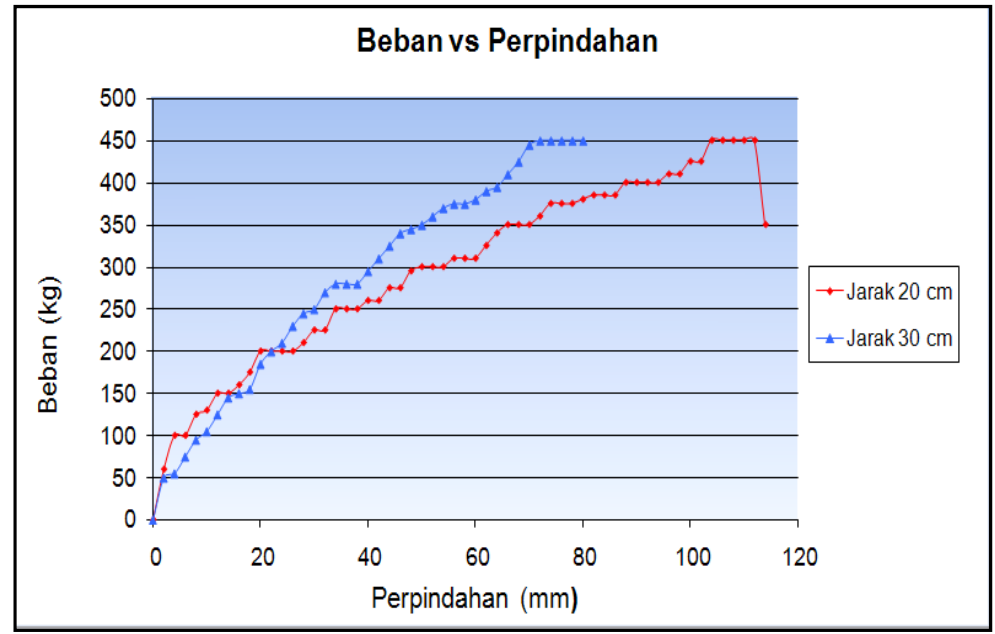

Gambar 14. Kurva Pushover Beban - Perpindahan

Pada portal dengan jarak sengkang $30 \mathrm{~cm}$, perpindahan yang terjadi sebesar $80 \mathrm{~mm}$ dan pada jarak sengkang $20 \mathrm{~cm}$ perpindahan yang terjadi sebesar $114 \mathrm{~mm}$. Dari hal ini dapat disimpulkan bahwa semakin rapat jarak sengkang yang diberikan, maka akan menambah perpindahan yang dapat diterima. Penulangan sengkang dengan jarak yang lebih rapat mempengaruhi daktail pada beton bertulang, karena semakin rapat jarak sengkang, maka akan meng-confined beton sekitarnya dengan baik, sehingga mempengaruhi daktail yang terjadi.

Kekakuan portal dengan jarak sengkang $20 \mathrm{~cm}$ sebelum mencapai beban $200 \mathrm{~kg}$ lebih besar dibandingkan dengan kekakuan portal dengan jarak sengkang $30 \mathrm{~cm}$. Hal ini dapat dilihat dari satu titik tinjau. Misalkan pada Gambar 14, pada beban $150 \mathrm{~kg}$ untuk jarak sengkang $20 \mathrm{~cm}$, perpindahan yang terjadi adalah $14 \mathrm{~mm}$, sedangkan portal dengan jarak sengkang $30 \mathrm{~cm}$ adalah 16 $\mathrm{mm}$. Artinya semakin besar perpindahan yang terjadi, maka akan membuat kekakuan struktur berkurang. 
Namun, setelah beban mencapai $200 \mathrm{~kg}$ lebih, kekakuan portal dengan jarak sengkang $20 \mathrm{~mm}$ menajdi lebih kecil dibandingkan dengan portal dengan jarak sengkang $30 \mathrm{~cm}$. Hal ini terlihat dari grafik beban - perpindahan pada Gambar 14, dimana portal dengan jarak sengkang $20 \mathrm{~cm}$ terjadi retak yang lebih banyak pada beton, sehingga mempengaruhi kekakuan dari struktur.

\subsection{Analisa Tegangan dan Regangan}

Tegangan - regangan beton bertulang diambil pada empat titik, yaitu jarak sengkang $30 \mathrm{~cm}$ pada beban $185 \mathrm{~kg}$ untuk titik tinjau $\mathrm{A}$, beban $450 \mathrm{~kg}$ dengan titik tinjau B, yaitu $500 \mathrm{~mm}$ kolom kanan sebelah kanan seperti terlihat pada Gambar 15.

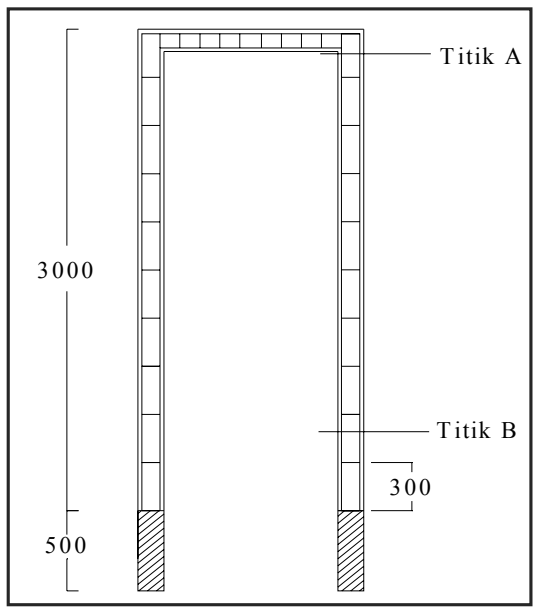

Gambar 15. Posisi Titik Tinjau Tegangan dan Regangan untuk Jarak Sengkang $30 \mathrm{~cm}$

Tabel 1. Nilai Tegangan - Regangan pada Beberapa Pembebanan di Titik A pada Portal dengan Jarak Sengkang $30 \mathrm{~cm}$ pada Beban $185 \mathrm{~kg}$

\begin{tabular}{|c|c|c|r|r|r|}
\hline Kondisi & $\boldsymbol{P}(\mathrm{N})$ & $\boldsymbol{\delta}(\mathrm{mm})$ & $\boldsymbol{M}(\mathrm{N} \cdot \mathrm{mm})$ & $\boldsymbol{f}_{\boldsymbol{c}}(\mathrm{MPa})$ & $\boldsymbol{\varepsilon}(\mathrm{mm} / \mathrm{mm})$ \\
\hline 0 & 0,00 & 0 & 0,00 & 0,000 & 0,000000 \\
\hline 1 & 133,06 & 14 & 922736,97 & 3,490 & 0,000187 \\
\hline 2 & 302,91 & 40 & 2084869,52 & 6,581 & 0,000374 \\
\hline 3 & 477,67 & $>80$ & 3280567,80 & 11,620 & 0,000748 \\
\hline 4 & 507,90 & $>80$ & 3487377,38 & 17,060 & 0,001496 \\
\hline 5 & 520,34 & $>80$ & 3572453,70 & 14,880 & 0,003000 \\
\hline
\end{tabular}

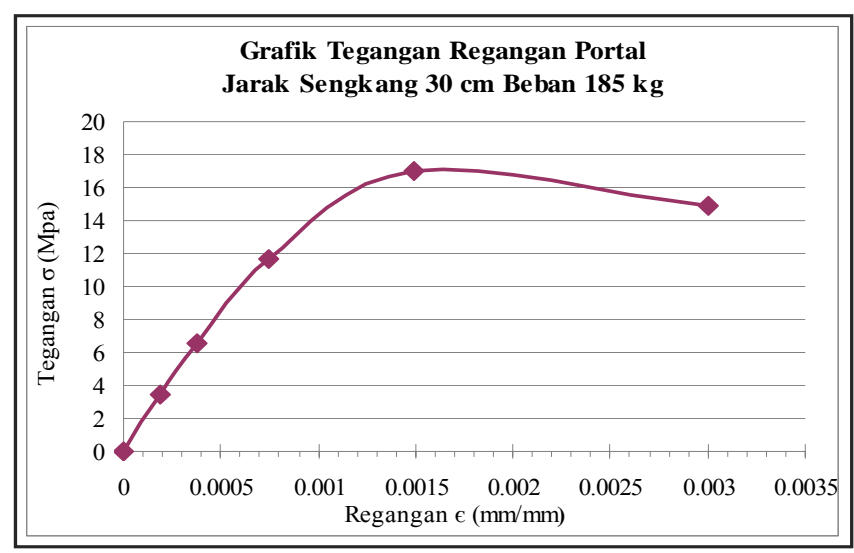

Gambar 16. Tegangan - Regangan Beton di Titik A untuk Jarak Sengkang 30 cm 
Tabel 2. Nilai Tegangan - Regangan pada Beberapa Pembebanan di Titik B pada Portal dengan Jarak Sengkang $30 \mathrm{~cm}$ pada Beban $450 \mathrm{~kg}$

\begin{tabular}{|c|c|c|c|c|c|}
\hline Kondisi & $\boldsymbol{P}(\mathrm{N})$ & $\boldsymbol{\delta}(\mathrm{mm})$ & $\boldsymbol{M}(\mathrm{N} . \mathrm{mm})$ & $\boldsymbol{f}_{\boldsymbol{c}}(\mathrm{MPa})$ & $\boldsymbol{\varepsilon}(\mathrm{mm} / \mathrm{mm})$ \\
\hline 0 & 0,00 & 0 & 0,00 & 0,000 & 0,000000 \\
\hline 1 & 337,63 & 46 & 1830791,87 & 6,661 & 0,000379 \\
\hline 2 & 606,34 & $>80$ & 3285433,03 & 11,731 & 0,000758 \\
\hline 3 & 644,25 & $>80$ & 3490636,71 & 17,120 & 0,001516 \\
\hline 4 & 659,18 & $>80$ & 3571458,52 & 14,810 & 0,003032 \\
\hline 5 & 659,36 & $>80$ & 3572453,70 & 14,880 & 0,003000 \\
\hline
\end{tabular}

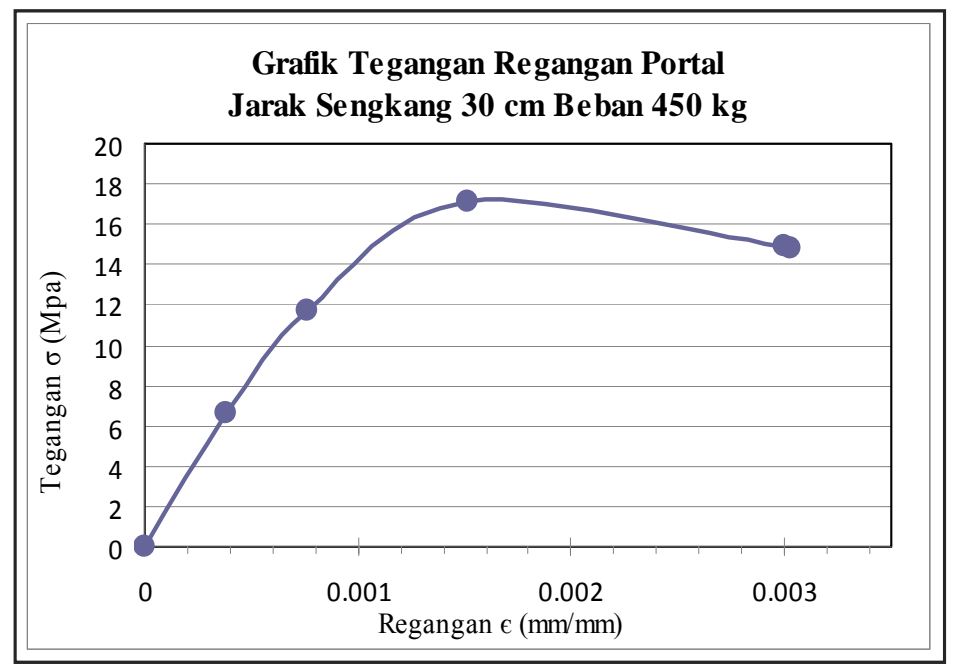

Gambar 17. Tegangan - Regangan Beton di Titik B untuk Jarak Sengkang 30 cm

Kemudian titik regangan-regangan lain yang diambil pada jarak sengkang $20 \mathrm{~cm}$ juga pada kolom kanan portal, beban $200 \mathrm{~kg}$ untuk titik A dan pada pembebanan $450 \mathrm{~kg}$ pada titik B, seperti terlihat pada Gambar 18.

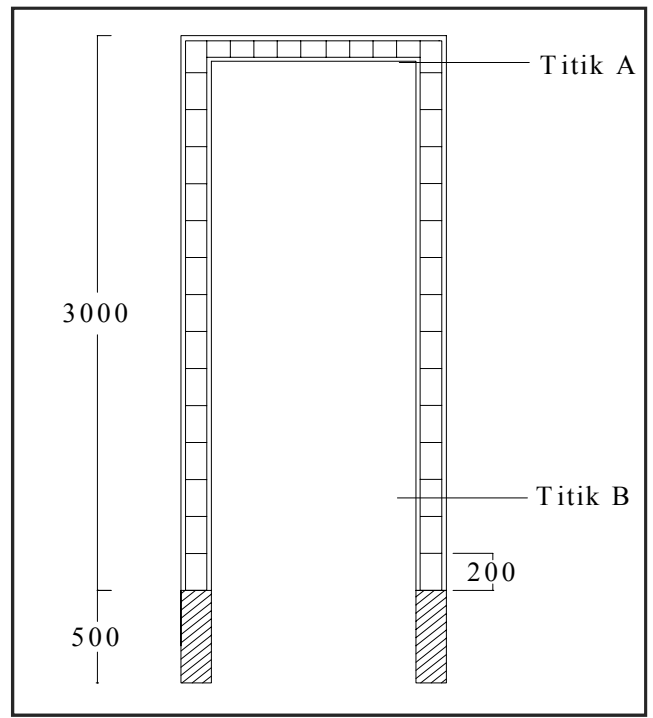

Gambar 18. Posisi Titik Tinjau untuk Jarak Sengkang 20 cm 
Tabel 3. Nilai Tegangan - Regangan pada Beberapa Pembebanan di Titik A pada Portal dengan Jarak Sengkang $20 \mathrm{~cm}$ pada Beban $200 \mathrm{~kg}$

\begin{tabular}{|c|c|c|c|r|r|}
\hline Kondisi & $\boldsymbol{P}(\mathrm{N})$ & $\boldsymbol{\delta}(\mathrm{mm})$ & $\boldsymbol{M}(\mathrm{N} . \mathrm{mm})$ & $\boldsymbol{f}_{\boldsymbol{c}}(\mathrm{MPa})$ & $\boldsymbol{\varepsilon}(\mathrm{mm} / \mathrm{mm})$ \\
\hline 0 & 0,00 & 0 & 0,00 & 0,000 & 0,000000 \\
\hline 1 & 144,34 & 12 & 999944,44 & 3,771 & 0,000203 \\
\hline 2 & 606,34 & $>112$ & 1955228,68 & 7,073 & 0,000406 \\
\hline 3 & 644,25 & $>112$ & 3309781,74 & 12,325 & 0,000812 \\
\hline 4 & 659,18 & $>112$ & 3506968,38 & 17,366 & 0,001624 \\
\hline 5 & 659,36 & $>112$ & 3572453,70 & 14,875 & 0,003000 \\
\hline
\end{tabular}

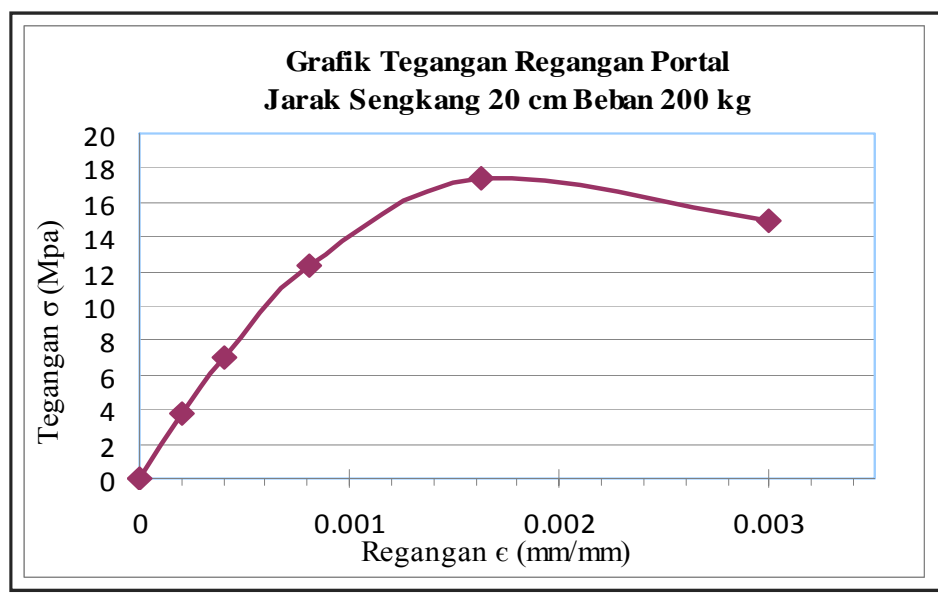

Gambar 19. Tegangan - Regangan Beton di Titik A untuk Jarak Sengkang 20 cm

Tabel 4. Nilai Tegangan - Regangan pada Beberapa Pembebanan di Titik B pada Portal dengan Jarak Sengkang $20 \mathrm{~cm}$ pada Beban $450 \mathrm{~kg}$

\begin{tabular}{|c|c|c|r|r|r|}
\hline Kondisi & $\boldsymbol{P}(\mathrm{N})$ & $\boldsymbol{\delta}(\mathrm{mm})$ & $\boldsymbol{M}(\mathrm{N} . \mathrm{mm})$ & $\boldsymbol{f}_{\boldsymbol{c}}(\mathrm{MPa})$ & $\boldsymbol{\varepsilon}(\mathrm{mm} / \mathrm{mm})$ \\
\hline 0 & 0,00 & 0 & 0,00 & 0,000 & 0,000000 \\
\hline 1 & 337,63 & 62 & 1830791,87 & 6,661 & 0,000379 \\
\hline 2 & 606,34 & $>112$ & 3285433,03 & 11,731 & 0,000758 \\
\hline 3 & 644,25 & $>112$ & 3490636,71 & 17,120 & 0,001516 \\
\hline 4 & 659,18 & $>112$ & 3584321,67 & 17,370 & 0,003000 \\
\hline
\end{tabular}

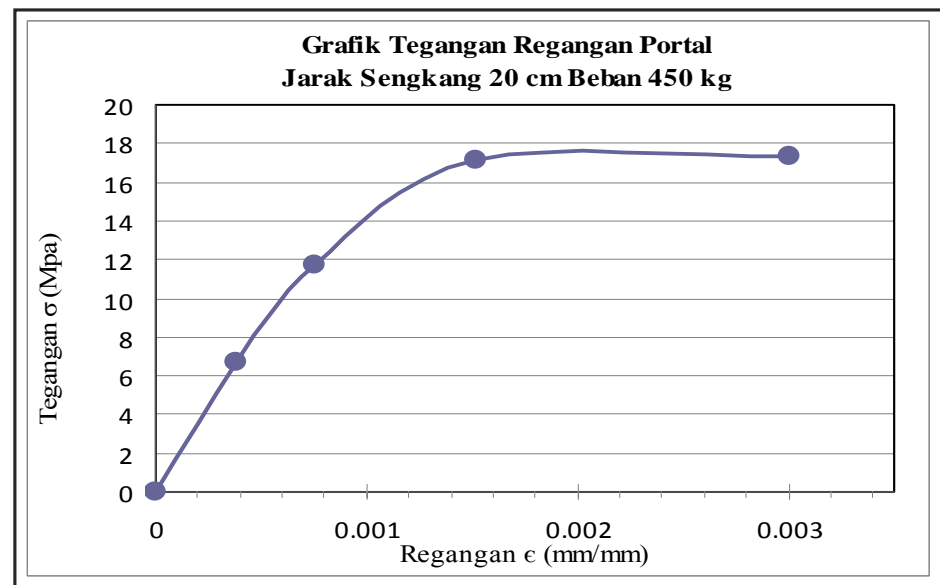

Gambar 20. Tegangan - Regangan Beton di Titik B untuk Jarak Sengkang 20 cm 


\section{KESIMPULAN}

Berdasarkan hasil studi eksperimental tersebut di atas, dapat diperoleh beberapa kesimpulan sebagai berikut :

1. Semakin rapat jarak sengkang pada kolom, maka akan menambah kekakuan, karena beton sekitarnya ter-confined dengan baik.

2. Retak geser yang terjadi tidak terlalu signifikan antara jarak sengkang $20 \mathrm{~cm}$ dan $30 \mathrm{~cm}$, hal ini dipengaruhi karena hanya beban horizontal yang ada pada struktur, tanpa memperhitungkan beban aksial yang ada.

3. Retak yang terjadi adalah retak lentur, dimana portal terlebih dahulu hancur akibat momen yang diakibatkan oleh beban luar yang bekerja. Retak geser tidak terlihat begitu jelas, hal ini terjadi karena penampang masih cukup kuat menahan gaya geser akibat beban luar, baik pada jarak sengkang $30 \mathrm{~cm}$, maupun pada jarak sengkang $20 \mathrm{~cm}$.

\section{DAFTAR PUSTAKA}

Boen, T., (1983), Manual Bangunan Tahan Gempa (Rumah Tinggal), Yayasan Lembaga Penyelidikan Masalah Bangunan.

Boen, T., (2000), Bangunan Rumah Tinggal Sederhana : Belajar dari Kerusakan Akibat Gempa, Prosiding Lokakarya Nasional Bangunan Sederhana Tahan Gempa, UII, Yogyakarta.

Boen, T., (2000), Gempa Bumi Bengkulu : Fenomena dan Perbaikan/ Perkuatan Bangunan (Bedasarkan Hasil Pengamatan Bangunan yang Rusak akibat Gempa Bumi Bengkulu 4 Juni 2000), Teddy Boen dan Rekan, Jakarta.

Boen, T., (1994), Manual Perbaikan Bangunan Sederhana yang Rusak Akibat Gempa Bumi.

SNI 03-1726-2002, Tata Cara Perencanaan Ketahanan Gempa Untuk Bangunan.

SNI 03-6816-2002, Tata Cara Pendetailan Penulangan Beton Bertulang Indonesia. 
Pengaruh Variasi J arak Sengkang Kolom untuk Rumah Sederhana Terhadap Beban Gempa di Padang

\section{8 | J URNAL REKAYASA SIPIL}

